\title{
PENINGKATAN HASIL BELAJAR HIMPUNAN DENGAN MENGGUNAKAN APLIKASI ISPRING SUITE 8
}

\author{
The Increase of Set Learning Outcomes \\ By Using iSpring Suite 8 Aplication
}

\author{
Rr. Martiningsih \\ SMP Muhammadiyah 1 Surabaya \\ Jalan Kapasan 73-75 Surabaya, Jawa Timur, Indonesia \\ tinink@gmail.com
}

\begin{abstract}
ABSTRAK: Permasalahan penelitian ini adalah kurangnya pemahaman peserta didik kelas VII B SMP Muhammadiyah 1 Surabaya tentang materi pelajaran Matematika, khususnya mengenai himpunan. Hal ini disebabkan oleh kurang tepatnya guru dalam memilih media pembelajaran yang digunakan. Tujuan penelitian ini adalah untuk meningkatkan kemampuan peserta didik dalam memahami himpunan menggunakan aplikasi iSpring Suite 8. Penelitian tindakan kelas ini dilaksanakan dengan dua siklus, di mana setiap siklus diawali dengan perencanaan, tindakan, observasi, dan refleksi. Subyek penelitian adalah peserta didik kelas VII B SMP Muhammadiyah 1 Surabaya tahun pelajaran 2017/2018 semester ganjil dengan jumlah peserta didik 36 orang. Data dalam penelitian ini berupa penilaian proses yang diperoleh dari peserta didik dalam beraktivitas dan penilaian pada akhir siklus. Kemudian, data dianalisis untuk memperoleh gambaran tentang berhasil tidaknya pembelajaran yang telah dilakukan. Ada peningkatan hasil belajar peserta didik dalam memahami himpunan setelah belajar menggunakan aplikasi iSpring Suite 8. Pada siklus pertama tanpa animasi rata-rata hasil belajar 78,89 dan pada siklus kedua sebesar 86,39 karena dengan variasi animasi, penambahan video, background yang lebih menarik. Pemanfaatan aplikasi iSpring Suite 8 dapat meningkatkan hasil belajar matematika materi himpunan kelas VII B SMP Muhammadiyah 1 tahun ajaran 2017/2018. Guru sebaiknya memperindah tampilan presentasinya dengan iSpring Suite 8 karena hasilnya lebih menawan dan mudah dimanfaatkan.
\end{abstract}

Kata Kunci: himpunan, hasil belajar, media pembelajaran, ispring Suite 8

ABSTRACT: The problem of this research is the lack of
understanding by students of class VII B SMP Muhammadiyah
1 Surabaya in Math, particularly in Set. This is because teachers
have chosen inappropriate learning media. The purpose of this
study is to improve the students' understanding on Set by using
iSpring Suite 8. This classroom action research is carried out
with two cycles, where each cycle has steps of planning, action,
observation, and reflection. The subjects of the study are the
students of class VII B SMP Muhammadiyah 1 Surabaya in the
academic year of 2017/2018 semester 1 with the total number
of 36 students. The data in this study is the assessment of the 
process obtained from learners in the activity and assessment at the end of the cycle. Then, the data are analyzed to get an idea of the success or failure of the learning that has been done. The result shows that there is an increase in learning outcomes of students in understanding the set after learning with ispring Suite 8 applications, without animation in the first cycle with average learning outcome of 78.89, and with animation, video, as well as more interesting background in the second cycle with average learning outcome os 86.39. Utilization of iSpring Suite 8 application can improve Set learning outcomes by the students of class VII B SMP Muhammadiyah 1 academic year 2017/2018.

Key words: Set, learning outcomes, iSpring Suite 8

\section{PENDAHULUAN}

Teknologi Informasi dan Komunikasi (TIK) telah menjadi kebutuhan yang penting dalam menentukan kualitas dan efektivitas proses pembelajaran (Alhamuddin, 2012: 1). Pemanfaatan TIK membantu pembelajaran menjadi lebih bermakna karena sangat membantu peserta didik memahami konsep materi yang diajarkan. Peran utama TIK dalam proses pembelajaran adalah menyediakan sumber belajar yang dapat mempermudah dan mempercepat pekerjaan peserta didik.

Pemanfaatan sumber belajar berbasis TIK bagi peserta didik dapat terjadi kapan saja dan di mana saja, tidak terbatas oleh ruang dan waktu (space and time). Baik proses penyajian materi pembelajaran maupun penyampaian gagasan dapat menjadi lebih menarik dan menyenangkan sehingga pada akhirnya tercapai standar kompetensi yang menjadi tujuan pembelajaran.

Usaha untuk mencapai kompetensi sebagaimana yang telah ditetapkan pada setiap jenjang dan satuan tingkat pendidikan, penguasaan kompetensi dikelompokkan menjadi beberapa kompetensi. Tingkat kompetensi menunjukkan tahapan yang harus dilalui untuk mencapai kompetensi lulusan yang telah ditetapkan dalam Standar Kompetensi Lulusan. Salah satu kompetensi yang harus dikuasai oleh peserta didik SMP kelas VII pada semester satu adalah menjelaskan dan menyatakan himpunan, himpunan bagian, himpunan semesta, himpunan kosong, komplemen himpunan, dan menggunakan masalah kontekstual.
Berdasarkan hasil pengamatan pendahuluan ditemukan bahwa selama pembelajaran berlangsung, guru tidak tepat memilih media pembelajaran atau sumber belajar untuk materi himpunan. Guru hanya menunjukkan media gambar yang ada di buku. Kondisi yang demikian ini mengakibatkan sebagian besar peserta didik kurang aktif, menganggap Matematika adalah pelajaran yang membosankan, dan banyak peserta didik yang tidak selesai dalam mengerjakan soal sesuai dengan waktu yang telah ditentukan. Peserta didik juga tampak tidak termotivasi mempelajari pelajaran Matematika. Guru perlu selalu berupaya menumbuhkan motivasi belajar peserta didik pada pelajaran Matematika.

Motivasi belajar adalah salah satu faktor yang turut menentukan keefektifan pembelajaran (Mulyasa, 2011: 112). Untuk memupus anggapan peserta didik tentang pelajaran Matematika yang sulit, seyogianya guru mengupayakan kemudahan mempelajarinya yaitu dengan menggunakan media pembelajaran yang sesuai. Menurut Mulyasa (2011: 52), kemudahan belajar diberikan melalui kombinasi antara pembelajaran individual personal dengan pengalaman. Semestinya guru harus mengenal karakteristik setiap media pembelajaran dan menguasai teknik-teknik penyajian agar guru mampu dan terampil menggunakannya sesuai dengan tujuan yang akan dicapai (Roestiyah, 2012: 3; Ardiansyah, 2016: 61). 
Jika seorang guru melakukan aktivitas pembelajaran, terjadilah aktivitas mengajar dan aktivitas belajar. Aktivitas mengajar menyangkut peranan seorang guru dalam konteks mengupayakan terciptanya jalinan komunikasi harmonis antara mengajar itu sendiri dengan pembelajar (Rohani, 2012: 4). Atas dasar pemikiran ini, penulis tergugah untuk melakukan penelitian tentang bagaimana penerapan iSpring Suite 8 sebagai upaya untuk meningkatkan hasil belajar peserta didik tentang pelajaran Matematika, khususnya materi himpunan.

Subyek penelitian adalah peserta didik kelas VII B SMP Muhammadiyah 1 tahun ajaran 2017/2018. Penggunaan aplikasi iSpring Suite 8 dianggap sesuai karena beberapa hasil penelitian tentang pemanfaatan TIK untuk keperluan pendidikan menurut Ibrahim (2004: 15) memberikan dampak positif.

Rumusan masalah dalam penelitian ini adalah mengenai bagaimana pemanfaatan aplikasi iSpring Suite 8 yang dapat meningkatkan hasil belajar Matematika, khususnya materi himpunan kelas VII B SMP Muhammadiyah 1 tahun ajaran 2017/2018. Tujuan penelitian adalah untuk mengetahui bagaimana penerapan iSpring Suite 8 yang dapat meningkatkan hasil belajar Matematika, khususnya materi himpunan pada kelas VII B SMP Muhammadiyah 1 tahun ajaran 2017/2018.

Manfaat dari penelitian ini adalah peserta didik diharapkan akan termotivasi untuk belajar Matematika karena guru menerapkan kegiatan pembelajaran yang menarik melalui pemanfaatan media pembelajaran. Guru memanfaatkan media pembelajaran karena menyadari bahwa mereka bukan lagi satusatunya sumber belajar bagi peserta didik. Kegiatan pembelajaran Matematika dan mata pelajaran lainnya hendaknya dilakukan dengan menggunakan media yang mampu menyenangkan peserta didik dan membuat mereka aktif belajar.

Seringkali pembelajaran untuk mata pelajaran tertentu kurang diminati siswa yang dapat dilihat dari sikap siswa yang cenderung malas belajar, cepat merasa bosan, dan tidak termotivasi dalam belajar. Akibatnya, pembelajaran tidak berjalan secara efektif dan menurunnya prestasi belajar siswa, baik secara individu maupun klasikal. Keaktifan siswa juga dirasakan kurang selama pembelajaran berlangsung (Ubaidah, 2016: 55).

Sebagian guru mungkin saja masih ada yang mengatakan bahwa mengajar dengan menggunakan buku teks saja peserta didiknya sudah memperlihatkan prestasi belajar yang memadai atau bahkan membanggakan. Kemungkinan sebagian guru lainnya juga ada yang mengatakan bahwa mencari sumber-sumber belajar lainnya di luar buku teks yang sudah ditetapkan atau tersedia tentulah menyita waktu di samping membutuhkan biaya. Sebagian guru lainnya kemungkinan juga mengatakan bahwa untuk apa repot-repot memikirkan pemanfaatan berbagai sumber belajar dalam kegiatan belajar-mengajar jika tidak ada konsekuensinya yang dapat dirasakan guru (Martiningsih, 2007: 164).

Guru perlu memotivasi peserta didik secara terus menerus agar mereka termotivasi untuk mempelajari materi pelajaran yang tidak mereka sukai. Sikap peserta didik yang tidak menyukai materi pelajaran tertentu ini dapat saja dikarenakan ketidakmampuan mereka menyelesaikan soal dengan tepat atau dapat juga diakibatkan pembelajaran itu sendiri yang tidak menyenangkan (Frengky, 2008: 152).

Guru harus mengupayakan kemudahan dalam belajar melalui pemanfaatan berbagai sumber belajar. Sumber belajar merupakan media yang dapat digunakan sebagai sarana komunikasi untuk menyalurkan pesan, merangsang pikiran, membangkitkan semangat, perhatian, serta kemauan siswa sehingga mendorong terjadinya proses belajar pada diri siswa (Wahyudi, 2016: 12). Kemudahan belajar dapat dilakukan antara lain melalui pemanfaatan media dalam pembelajaran. Penggunaan media pembelajaran yang tepat dapat membantu proses penyampaian informasi atau pesan dalam pembelajaran berlangsung secara efektif (Sunaengsih, 2016: 184).

Penelitian ini memanfaatkan aplikasi iSpring Suite 8 yaitu salah satu aplikasi 
favorit yang dipakai karena mudah dimengerti dan praktis digunakan untuk membuat konten pembelajaran (Rahmah, 2017: 3).

Mengingat kerumitan pembuatan Flash pada tampilan presentasi, beberapa vendor perangkat lunak mengeluarkan produkproduk yang memudahkan pembuatan konten berbasis Flash. Dengan menggunakan alat bantu ini, seseorang dapat membuat konten Flash tanpa harus menguasai pemrograman. Kebanyakan alat bantu ini menggunakan aplikasi PowerPoint, baik untuk pembuatan disain, animasi maupun narasi/suara (Tamimuddin, 2014: 3).

Salah satu software yang dapat mengonversi PowerPoint ke bentuk Flash adalah iSpring Suite 8. Software iSpring Suite 8 adalah program yang berjalan "menumpang" pada piranti lunak yang sudah ada, dalam hal ini MS PowerPoint, yang secara umum dikenal sebagai Add program. Artinya, iSpring Suite 8 tidak dapat berjalan sebelum program MS PowerPoint terpasang pada perangkat komputer. Selain harus terpasang MS PowerPoint, komputer juga harus sudah terpasang flash player. Hal ini diharuskan karena ispring Suite 8 menyediakan fasilitas untuk mengubah dokumen MS PowerPoint menjadi file flash, menyisipkan file flash ke dalam MS PowerPoint. Untuk mendukung fasilitas tersebut, iSpring Suite 8 memerlukan plug player.

Adapun langkah-langkah mengonversi PowerPoint dalam bentuk Flash sebagai berikut: (1) Jika belum memiliki software iSpring Suite 8, pertama-tama yang perlu terlebih dahulu dilakukan adalah mengunduh software-nya; (2) Meng-install software iSpring Suite 8 pada komputer anda; (3) PowerPoint yang sudah selesai di-publish. Klik iSpring Suite 8 dan kemudian pilih Publish; (4) Pilih settingan flash anda; dan (5) Jika setingannya sudah selesai, klik Publish (Tamimuddin, 2014: 3)

Wagino telah melakukan penelitian dengan memanfaatkan software iSpring yang kesimpulannya adalah bahwa: (1) sebagian besar peserta sangat antusias karena materi yang diberikan sangat bermanfaat dan menarik bagi peserta; dan (2) materi pelatihan pembuatan media pembelajaran interaktif dengan perangkat lunak iSpring Presenter disertai praktek mandiri dan tanya jawab langsung dapat mempercepat proses belajar (Wagino, 2015: 22).

Suprapti juga telah melakukan penelitian dengan memanfaatkan software iSpring. Hasil penelitiannya menyatakan bahwa Permainan Media Microsoft Powerpoint ispring merupakan alat permainan yang dapat meningkatkan kemampuan Matematika pada anak di mana anak bermain mengenal konsep angka dan lebih bisa mengurutkan, membilang, dan menghubungkan jumlah benda-benda dengan angka (Suprapti, 2015: 1).

\section{METODA}

Metoda yang digunakan di dalam penelitian ini adalah alur Penelitian Tindakan Kelas (PTK) yang meliputi perencanaan tindakan, pelaksanaan tindakan, observasi, dan refleksi. Pada tahapan awal, kegiatannya berupa penyusunan rancangan tindakan yang menjelaskan tentang apa, mengapa, kapan, di mana, oleh siapa dan bagaimana kegiatan tersebut dilakukan (Suhardjono, 2011: 78).

Pada setiap siklus, kegiatan yang dilakukan pada tahap perencanaan adalah: (1) melakukan pertemuan dengan teman sejawat selaku pengamat untuk membicarakan persiapan kegiatan pembelajaran yang dilakukan pada saat pembelajaran Matematika dengan bantuan aplikasi iSpring Suite 8; (2) mendiskusikan dan menetapkan RPP yang akan diterapkan di kelas sebagai tindakan penelitian; (3) mempersiapkan bahan yang diperlukan untuk melaksanakan penelitian yaitu berupa media pembelajaran yang telah dilengkapi aplikasi iSpring Suite 8; (4) mempersiapkan waktu dan cara pelaksanaan, diskusi hasil pengamatan pada subyek penelitian; (5) mempersiapkan buku perekam data; dan (6) mempersiapkan perangkat tes hasil belajar pada setiap siklus. Pelaksanaan tindakan pada setiap siklus adalah sebagai berikut.

Siklus pertama adalah melaksanakan kegiatan pembelajaran yang berpedoman pada RPP yang telah dibuat. Langkah 
pertamanya adalah mengamati media yang telah didesain dengan aplikasi iSpring Suite 8.

Langkah kedua adalah menanya, yaitu bertanya kepada peserta didik tentang pengertian himpunan, bukan himpunan, dan notasi pembentuk himpunan. Menanyakan pula mana yang termasuk anggota himpunan dan mana yang bukan anggota himpunan. Pada tahap ini, secara mudah dapat disajikan pola gambar himpunan dengan aplikasi iSpring Suite 8 yaitu untuk himpunan semesta, himpunan A, dan himpunan B.

Langkah ketiga yaitu mengeksplorasi, di mana peserta didik berdiskusi dan berkerja berkelompok untuk mencermati: (1) himpunan yang disajikan; dan (2) permasalahan terkait pengertian himpunan dan bukan himpunan, notasi pembentuk himpunan, dan anggota himpunan, serta bukan anggota himpunan. Langkah keempat adalah mengasosiasi, yaitu peserta didik menyimpulkan permasalahan yang dibahas misalnya bahwa "himpunan adalah kumpulan segala sesuatu yang jelas definisinya". Untuk mengetahui pemahaman peserta didik terhadap materi yang dipelajari, peserta didik diminta untuk mengerjakan latihan. Selanjutnya, langkah kelima yaitu mengomunikasikan, di mana salah satu anggota kelompok mempresentasikan hasil diskusi kegiatan sebelumnya. Sementara itu, peserta didik yang lain memberikan tanggapan terhadap materi presentasi, baik dalam bentuk tanya jawab untuk mengonfirmasi, melengkapi informasi, maupun tanggapan lainnya.

Siklus kedua adalah melaksanakan kegiatan pembelajaran dengan berpedoman pada RPP yang telah dibuat. Langkah pertama yaitu mengamati media yang telah didesain dengan aplikasi iSpring Suite 8, di mana ada perbaikan pada hyperlink dan warna slide. Langkah kedua yaitu menanya, di mana guru bertanya kepada peserta didik tentang operasi pada himpunan dan cara mudah untuk menentukan bilangan yang dicari dari pola yang disajikan. Pada tahap ini, aplikasi iSpring Suite 8 menyajikan rumus Un untuk himpunan. Langkah ketiga yaitu mengeksplorasi, di mana peserta didik berdiskusi berkerja berkelompok untuk mencermati pola-pola yang ada dan permasalahan terkait pola. Langkah keempat yaitu mengasosiasi, di mana peserta didik menyimpulkan pola yang ada. Kemudian, untuk mengetahui pemahaman materi yang dipelajari, peserta didik diberikan kesempatan untuk mengerjakan latihan. Langkah kelima yaitu mengomunikasikan, di mana salah satu anggota kelompok mempresentasikan hasil diskusi kegiatan sebelumnya. Sementara peserta didik lainnya memberikan tanggapan terhadap materi presentasi dalam bentuk tanya jawab, baik untuk mengonfirmasi, melengkapi informasi maupun tanggapan lainnya, dan melakukan penilaian menggunakan alat penilaian yang telah disediakan.

Kegiatan pada saat observasi adalah: (1) teman sejawat mencatat semua aktivitas yang dilakukan guru dan peserta didik selama proses pembelajaran, yaitu mulai kegiatan awal hingga kegiatan akhir; dan (2) melakukan observasi dengan instrumen observasi. Kemudian, pada saat refleksi, kegiatan yang dilakukan adalah: (1) menganalisis catatan di lapangan dan jurnal harian sebagai hasil pengamatan saat pembelajaran di kelas, untuk selanjutnya dikaji dan dicermati kembali; (2) data yang terkumpul dikaji secara komprehensif; (3) data dibahas bersama pengamat untuk mendapat kesamaan pandangan terhadap tindakan pada setiap siklus; dan (4) hasil refleksi dijadikan bahan untuk merevisi rencana tindakan berikutnya.

Pedoman yang digunakan untuk menentukan keberhasilan pelaksanaan penelitian ini adalah: (1) prestasi belajar peserta didik meningkat kualitasnya setelah dilakukan tindakan yaitu dengan membandingkan prestasi belajar peserta didik sebelum dan setelah dilaksanakan tindakan; dan (2) kualitas proses pembelajaran menunjukkan peningkatan setelah dilakukan tindakan yaitu dengan membandingkan proses pembelajaran sebelum dan setelah dilaksanakan tindakan.

Subyek penelitian adalah peserta didik kelas VII B SMP Muhammadiyah 1 Surabaya Tahun Pelajaran 2017/2018. Jumlah peserta 
didik kelas VII B adalah 38 orang. Penelitian ini-dilaksanakan pada bulan September 2017 dan dibatasi hanya untuk mata pelajaran Matematika dengan materi himpunan melalui pemanfaatan aplikasi iSpring Suite 8. Teknik pengumpulan data menggunakan teknik observasi dan dokumentasi. Penggunaan instrumen observasi ditujukan untuk pengumpulan data pengamatan lapangan.

Data yang telah dikumpulkan dianalisis berdasarkan perubahan yang terjadi pada setiap siklus tentang proses pembelajaran yang menyenangkan dan bermakna sebagai bentuk pengalaman belajar. Teknik analisis data yang digunakan adalah teknik deskriptif komparatif yaitu membandingkan keberhasilan antara siklus yang satu dengan siklus berikutnya. Penelitian ini juga menggunakan teknik analisis data kuantitatif, yaitu untuk menggambarkan kenyataan atau fakta sesuai dengan data yang diperoleh dengan tujuan untuk mengetahui hasil belajar yang dicapai peserta didik.

Evaluasi dilakukan tiap akhir siklus untuk mengetahui tingkat keberhasilan peserta didik setelah mengikuti proses pembelajaran. Evaluasi dilakukan dengan cara memberikan tes tertulis. Di dalam analisis ini, perhitungan dilakukan dengan menggunakan statistik sederhana, yaitu ketuntasan belajar. Seorang peserta didik dikatakan telah tuntas belajarnya apabila yang bersangkutan telah mencapai nilai 75 dalam rentangan nilai 0-100. Kelas dikatakan tuntas belajar apabila di kelas tersebut terdapat $80 \%$ peserta didik yang telah mencapai daya serap lebih dari atau sama dengan 75 .

\section{HASIL DAN PEMBAHASAN}

\section{Peningkatan Hasil Belajar Himpunan Dengan iSpring Suite 8}

Berdasarkan hasil pengamatan pada siklus pertama, ditemukan bahwa selama pembelajaran berlangsung, sebagian besar peserta didik telah tertib ketika proses pembelajaran dan guru tidak perlu selalu mengingatkan mereka agar memperhatikan penjelasan guru. Peserta didik lebih bersemangat tetapi masih cenderung pasif.
Minat belajar peserta didik dalam pembelajaran tampak lebih baik daripada sebelumnya yang ditandai dengan banyaknya peserta didik yang antusias mempelajari operasi pada himpunan selama pembelajaran berlangsung. Berdasarkan tes, hasil belajar peserta didik pada siklus pertama, rata-rata 78,89 dan yang tuntas sebanyak 27 peserta didik $(75,00 \%)$ serta yang tidak tuntas sebanyak 9 peserta didik (25,00\%). Pada siklus pertama, pemanfaatan iSping Suite 8 masih sederhana dengan hyperlink sederhana.

Tabel 1. Deskripsi Hasil Belajar Matematika Siklus Pertama

\begin{tabular}{ccc}
\hline Nilai & Frekuensi & Persentase \\
\hline 60 & 4 & 11,11 \\
70 & 5 & 13,89 \\
80 & 18 & 50,00 \\
90 & 9 & 25,00 \\
100 & 0 & 0,00 \\
& & \\
\hline Rata-rata & & $\mathbf{7 8 , 8 9}$ \\
\hline Ketuntasan & & $\mathbf{7 5 , 0 0}$ \\
\hline
\end{tabular}

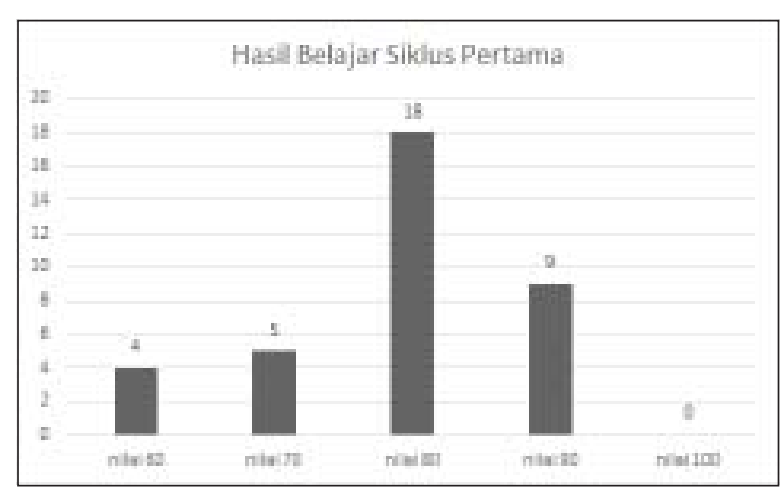

Gambar 1. Deskripsi Hasil Belajar Siklus Pertama

Berdasarkan hasil tes pada pembelajaran siklus pertama, didapatkan rata-rata hasil belajar siswa sebesar 78,89 dengan jumlah siswa yang tuntas sebanyak 27 siswa $(75,00 \%)$ dan yang tidak tuntas sebanyak 9 siswa $(25,00 \%)$.

Hasil observasi pembelajaran yang memanfaatkan aplikasi iSpring Suite 8 pada siklus pertama memberikan informasi atau gambaran tentang sikap dan kesungguhan peserta didik. Perhatian peserta didik mulai terpusat pada pelajaran walaupun belum maksimal. Sedangkan semangat peserta didik dalam mengikuti pelajaran operasi pada 
himpunan mulai meningkat jika dibandingkan dengan kondisi awal. Perilaku yang menunjukkan peningkatan adalah dalam menunjukkan mana yang irisan, mana yang gabungan, selisih, dan komplemen yang dicari berdasarkan pengamatan dari pemanfaatan aplikasi iSpring Suite 8. Tugas yang diberikan kepada peserta didik dapat diselesaikan dengan baik walaupun belum tepat waktu semuanya. Tampak juga adanya peningkatan kemampuan peserta didik dalam menyelesaikan masalah sehari-hari yang berkaitan dengan operasi pada himpunan.

Kemudian, peserta didik mampu membuat diagram Venn dengan mengembangkan pola batang korek api yang telah ditayangkan dengan aplikasi iSpring Suite 8 sekalipun mereka belum dapat menyelesaikan tugas lebih awal dari waktu yang ditentukan. Keadaan yang demikian ini dapat saja disebabkan peserta didik belum terbiasa menyelesaikan tugas dengan cepat. Namun kemampuan membuat diagram Venn dari operasi pada himpunan melalui pemanfaatan penerapan aplikasi ispring Suite 8 memperlihatkan adanya peningkatan hasil belajar peserta didik.

Kemampuan guru juga tampak mulai memperlihatkan adanya peningkatan walaupun belum signifikan. Guru telah mampu mengelola kelas dalam pemanfaatan aplikasi iSpring Suite 8 dengan baik, memfasilitasi peserta didik, mampu menggunakan strategi pembelajaran, mampu berinteraksi dengan peserta didik, dan mengevaluasi kegiatan pembelajaran dengan baik. Mengingat pada siklus pertama ini, guru baru memulai memanfaatkan aplikasi iSpring Suite 8 dalam pembelajaran, pengaturan waktu masih perlu diperbaiki.

Tabel 2. Deskripsi Hasil Belajar Matematika Siklus Kedua

\begin{tabular}{ccc}
\hline Nilai & Frekuensi & Persentase \\
\hline 60 & 0 & 0,00 \\
70 & 0 & 0,00 \\
80 & 16 & 44,44 \\
90 & 17 & 47,22 \\
100 & 3 & 8,33 \\
\hline Rata-rata & & $\mathbf{8 6 , 3 9}$ \\
\hline Ketuntasan & & $\mathbf{1 0 0 , 0 0}$ \\
\hline
\end{tabular}

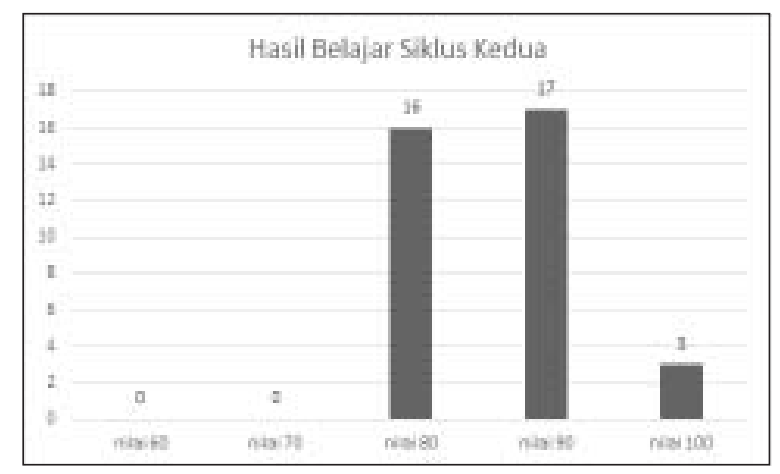

Gambar 2. Deskripsi Hasil Belajar Siklus Kedua

Berdasarkan hasil tes belajar peserta didik pada pembelajaran siklus kedua, rata-rata nilainya adalah sebesar 86,39 dan yang tuntas sebanyak 36 peserta didik (100\%) dan tidak ada yang tidak tuntas. Siklus kedua lebih berhasil karena ispring Suite 8 didesain lebih menarik dengan penambahan animasi, video dan gambar. Peserta didik lebih aktif dalam pembelajaran operasi pada himpunan. Peserta didik memperlihatkan peningkatan kinerja dan antusias belajarnya serta lebih aktif dalam pembelajaran operasi pada himpunan. Pada kegiatan pembelajaran, keaktifan peserta didik perlu ditingkatkan dengan cara memberi penghargaan kepada mereka yang berhasil baik belajarnya tentang operasi pada himpunan.

Tabel 2 di atas menunjukkan bahwa melalui kegiatan pembelajaran Matematika yang memanfaatkan aplikasi iSpring Suite 8 yang telah diperkaya dengan hyperlink dan tampilan slide yang lebih bervariasi dengan animasi dan video pada siklus 2 memberikan hasil 100\% tuntas, yaitu mendapatkan nilai minimal 80 dengan KKM yang ditentukan yaitu 75 dan nilai rata-rata hasil belajar adalah 86,39. Hasil belajar peserta didik selengkapnya disajikan pada Tabel 3.

Berdasarkan hasil observasi pada siklus kedua pembelajaran Matematika dengan memanfaatkan aplikasi ispring Suite 8, tampak adanya peningkatan. Peserta didik lebih bersemangat mengikuti pelajaran Matematika dan kemampuan mereka menentukan bilangan yang dimaksud pada pola tertentu yang disajikan mengalami peningkatan. Peserta didik lebih fokus mempelajari Matematika khususnya mengenai materi himpunan. 
Tabel 3 Hasil Belajar Peserta didik Secara Lengkap

\begin{tabular}{|c|c|c|c|}
\hline No & $\begin{array}{l}\text { Sebelum } \\
\text { Tindakan }\end{array}$ & $\begin{array}{c}\text { Siklus } \\
\text { Pertama }\end{array}$ & $\begin{array}{l}\text { Siklus } \\
\text { Kedua }\end{array}$ \\
\hline 1 & 60 & 80 & 90 \\
\hline 2 & 70 & 80 & 90 \\
\hline 3 & 60 & 80 & 90 \\
\hline 4 & 70 & 80 & 80 \\
\hline 5 & 50 & 80 & 90 \\
\hline 6 & 80 & 80 & 90 \\
\hline 7 & 80 & 90 & 80 \\
\hline 8 & 70 & 80 & 80 \\
\hline 9 & 80 & 90 & 90 \\
\hline 10 & 80 & 80 & 90 \\
\hline 11 & 60 & 80 & 80 \\
\hline 12 & 70 & 90 & 90 \\
\hline 13 & 70 & 80 & 80 \\
\hline 14 & 80 & 90 & 90 \\
\hline 15 & 70 & 70 & 80 \\
\hline 16 & 60 & 70 & 90 \\
\hline 17 & 70 & 80 & 90 \\
\hline 18 & 70 & 80 & 100 \\
\hline 19 & 60 & 60 & 80 \\
\hline 20 & 60 & 80 & 90 \\
\hline 21 & 60 & 60 & 90 \\
\hline 22 & 60 & 70 & 90 \\
\hline 23 & 60 & 70 & 80 \\
\hline 24 & 60 & 60 & 80 \\
\hline 25 & 70 & 80 & 80 \\
\hline 26 & 50 & 60 & 80 \\
\hline 27 & 70 & 80 & 80 \\
\hline 28 & 70 & 80 & 80 \\
\hline 29 & 80 & 90 & 100 \\
\hline 30 & 80 & 90 & 100 \\
\hline 31 & 80 & 90 & 90 \\
\hline 32 & 80 & 90 & 90 \\
\hline 33 & 70 & 80 & 80 \\
\hline 34 & 80 & 90 & 90 \\
\hline 35 & 70 & 80 & 80 \\
\hline 36 & 60 & 70 & 80 \\
\hline Rata-rata & 68,61 & 78,89 & 86,39 \\
\hline Tuntas & 10 & 27 & 36 \\
\hline $\begin{array}{l}\text { Tidak } \\
\text { Tuntas }\end{array}$ & 26 & 9 & 0 \\
\hline \% Tuntas & 27,78 & 75,00 & 100,0 \\
\hline $\begin{array}{c}\text { \%Tidak } \\
\text { Tuntas }\end{array}$ & 72,22 & 25,00 & 0,00 \\
\hline
\end{tabular}

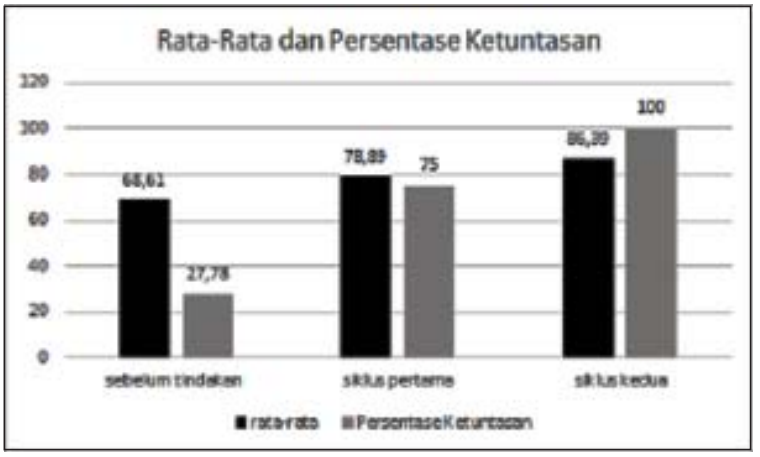

Gambar 3 Rata-Rata Hasil Belajar dan Persentase Ketuntasan Peserta Didik

Dengan demikian, dapatlah dikatakan bahwa potret pembelajaran operasi pada himpunan sudah mencapai tujuan yang tertuang di dalam indikator kinerja, yakni $\geq$ $80 \%$ dari jumlah peserta didik dalam kelas telah mencapai ketuntasan belajar individual. Oleh karena itu, kegiatan pembelajaran Matematika pada materi operasi pada himpunan yang memanfaatkan aplikasi iSpring Suite 8 pada siklus 2 dinyatakan berhasil sehingga tidak perlu diadakan siklus berikutnya.

Keaktifan belajar peserta didik tampak semakin meningkat dan mereka semua mengikuti pelajaran dengan penuh semangat dan tidak ada yang malas atau kurang bersemangat mengikuti pelajaran Matematika khususnya materi operasi pada himpunan. Hal ini dikarenakan pembelajaran yang dilaksanakan dengan memanfaatkan aplikasi iSpring Suite 8 sangat menarik minat belajar peserta didik.

Selanjutnya, sebagai suatu kesimpulan, dapat dikatakan bahwa indikator tindakan penelitian yang menyatakan bahwa (1) guru terampil mengelola proses pembelajaran Matematika tentang materi operasi pada himpunan dengan memanfaatkan aplikasi iSpring Suite 8; (2) terjadi perubahan sikap dan perilaku peserta didik dalam mengikuti pembelajaran Matematika yang ditandai dengan aktivitas peserta didik minimal baik dalam lembar observasi; dan (3) peserta didik kelas VII B SMP Muhammadiyah 1 Surabaya telah berhasil mengalami ketuntasan belajar dalam materi himpunan (nilai $\geq 75,0$ ).

Kualitas proses pembelajaran sebelum dilakukan tindakan selama siklus pertama dan 
siklus kedua disajikan pada Tabel 4 berikut ini:

Tabel 4. Suasana Pembelajaran yang Menyenangkan

\begin{tabular}{lccc}
\hline Indikator & $\begin{array}{c}\text { Sebelum } \\
\text { Tindakan }\end{array}$ & $\begin{array}{c}\text { Siklus } \\
\text { Pertama }\end{array}$ & $\begin{array}{c}\text { Siklus } \\
\text { Kedua }\end{array}$ \\
\hline $\begin{array}{l}\text { Belajar } \\
\text { dengan } \\
\text { gembira }\end{array}$ & 2 & 3 & 4 \\
\hline $\begin{array}{l}\text { Bersikap } \\
\text { akrab } \\
\text { dengan } \\
\text { guru }\end{array}$ & 2 & 3 & 4 \\
\hline $\begin{array}{l}\text { Belajar } \\
\text { tanpa } \\
\text { tertekan }\end{array}$ & 2 & 3 & 4 \\
\hline $\begin{array}{l}\text { Bersikap } \\
\text { akrab } \\
\text { dengan } \\
\text { teman }\end{array}$ & 2 & 3 & 3 \\
\hline $\begin{array}{l}\text { Bersikap } \\
\text { terbuka } \\
\text { dengan } \\
\text { guru. }\end{array}$ & 1 & 2 & 3 \\
\hline $\begin{array}{l}\text { Jumlah } \\
\text { Rata-rata }\end{array}$ & 1,8 & Cukup & \\
\hline Kriteria & Kurang & & \\
\hline & & 2 & \\
\hline
\end{tabular}

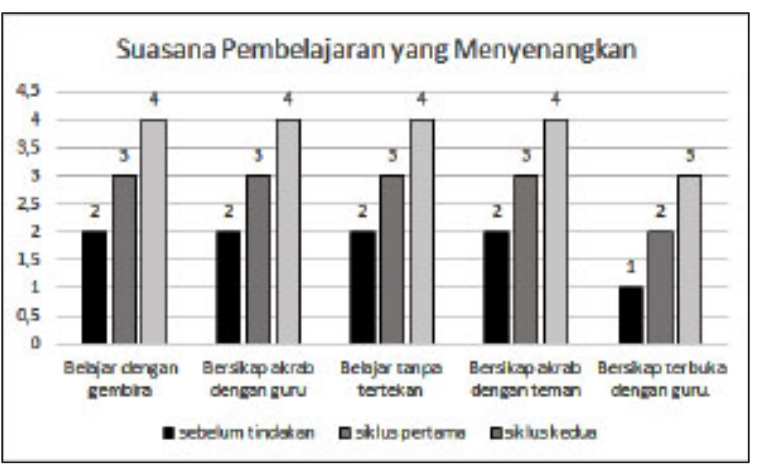

Gambar 4 Suasana Pembelajaran yang Menyenangkan

Dari Tabel 4 dan Gambar 4 di atas, dapat diketahui bahwa suasana pembelajaran semakin menyenangkan pada siklus kedua.
Tabel 5. Fokus Pembelajaran

\begin{tabular}{lccc}
\hline Indikator & $\begin{array}{c}\text { Sebelum } \\
\text { Tindakan }\end{array}$ & $\begin{array}{c}\text { Siklus } \\
\text { Pertama }\end{array}$ & $\begin{array}{c}\text { Siklus } \\
\text { Kedua }\end{array}$ \\
\hline $\begin{array}{l}\text { Lebih banyak } \\
\text { melakukan }\end{array}$ & 2 & 3 & 4 \\
\hline Fokus kegiatan & 2 & 3 & 4 \\
\hline Mencari sendiri & 2 & 3 & 4 \\
\hline Jumlah & 6 & 9 & 12 \\
\hline Rata-rata & 2 & 3 & 4 \\
\hline Kriteria & Cukup & Baik & $\begin{array}{c}\text { Sangat } \\
\text { Baik }\end{array}$ \\
\hline
\end{tabular}

Dari Tabel 5 di atas, dapat diketahui bahwa peserta didik lebih fokus dalam pembelajaran Matematika dengan aplikasi iSpring Suite 8.

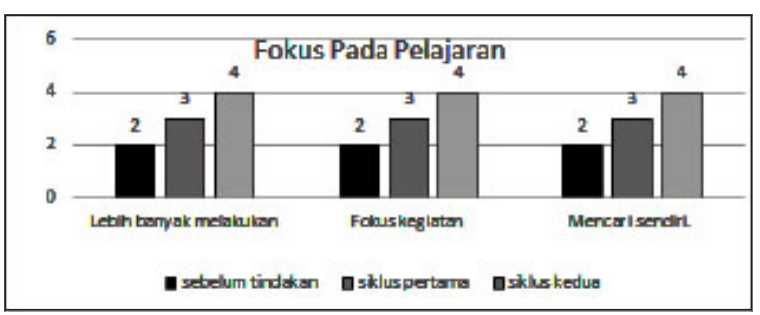

Gambar 5. Fokus Pada Pembelajaran

Tabel 6. Tanggung Jawab

\begin{tabular}{llcl}
\hline Indikator & $\begin{array}{c}\text { Sebelum } \\
\text { Tindakan }\end{array}$ & $\begin{array}{c}\text { Siklus } \\
\text { Pertama }\end{array}$ & $\begin{array}{c}\text { Siklus } \\
\text { Kedua }\end{array}$ \\
\hline $\begin{array}{l}\text { Tanggung jawab } \\
\text { mengerjakan tugas }\end{array}$ & 2 & 3 & 4 \\
\hline $\begin{array}{l}\text { Mengerjakan tugas } \\
\text { sesuai dengan } \\
\text { yang ditugaskan }\end{array}$ & 2 & 3 & 4 \\
\hline $\begin{array}{l}\text { Mempersiapkan } \\
\text { alat-alat pembelajaran } \\
\text { dengan baik. }\end{array}$ & 1 & 3 & 4 \\
\hline $\begin{array}{l}\text { Antusias peserta didik } \\
\text { dalam mengerjakan } \\
\text { tugas. }\end{array}$ & 2 & 3 & 4 \\
\hline $\begin{array}{l}\text { Tepat waktu dalam } \\
\text { mengerjakan tugas }\end{array}$ & 1 & 2 & 3 \\
\hline $\begin{array}{l}\text { Jumlah } \\
\text { Rata-rata }\end{array}$ & 8 & 14 & 19 \\
\hline Kriteria & Kurang & 2,8 & 3,8 \\
\hline
\end{tabular}

Rr. Martiningsih: Peningkatan Hasil Belajar Himpunan dengan Menggunakan Aplikasi iSpring Suite 8 


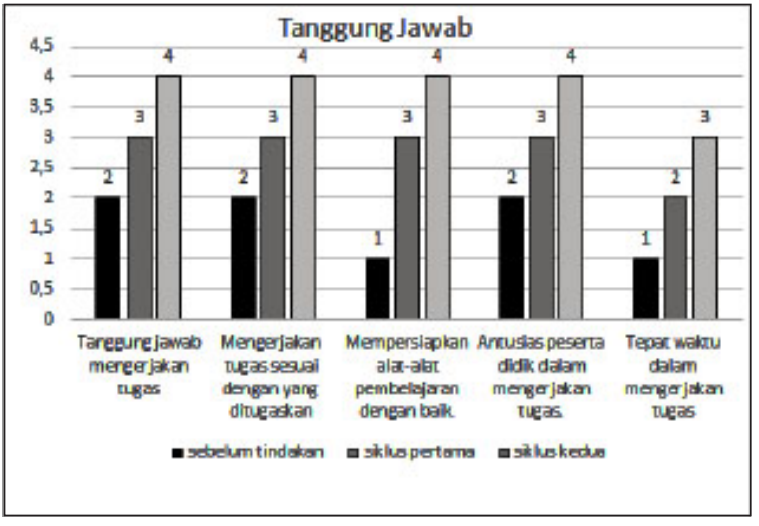

Gambar 6 . Tanggung Jawab

Tabel 7. Percaya Diri

\begin{tabular}{lccc}
\hline Indikator & $\begin{array}{c}\text { Sebelum } \\
\text { Tindakan }\end{array}$ & $\begin{array}{c}\text { Siklus } \\
\text { Pertama }\end{array}$ & $\begin{array}{c}\text { Siklus } \\
\text { Kedua }\end{array}$ \\
\hline $\begin{array}{l}\text { Pembelajaran } \\
\text { mendorong } \\
\text { peserta didik } \\
\text { untuk } \\
\text { percaya diri }\end{array}$ & 1 & 2 & 3 \\
\hline $\begin{array}{l}\text { Berani untuk } \\
\text { mengajukan } \\
\text { pendapat. }\end{array}$ & 2 & 3 & 4 \\
\hline $\begin{array}{l}\text { Kualitas } \\
\text { pertanyaan/ } \\
\text { jawaban yang } \\
\text { muncul }\end{array}$ & 1 & 3 & 4 \\
\hline $\begin{array}{l}\text { Jumlah } \\
\text { Rata-rata }\end{array}$ & 1,3 & 2,7 & 3,7 \\
\hline Kriteria & Kurang & Cukup & Baik \\
\hline
\end{tabular}

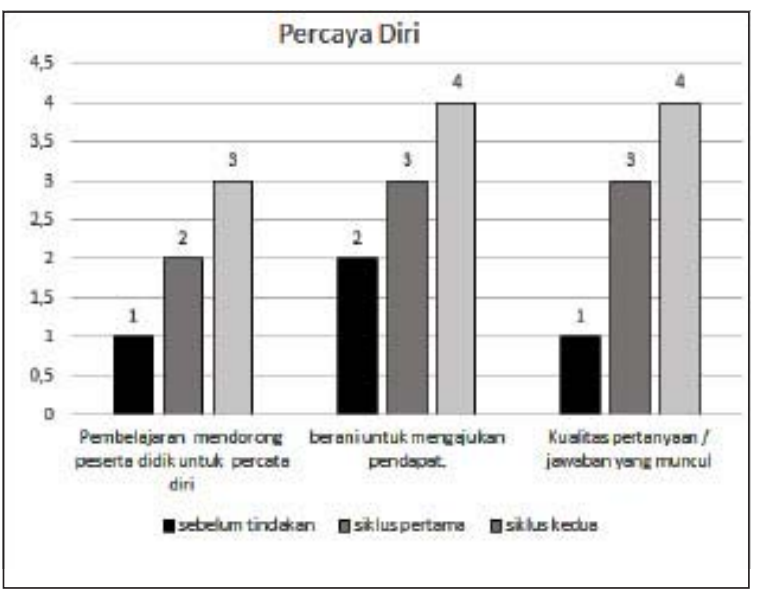

Gambar 7. Percaya Diri
Kriteria di atas, yang tercakup dalam pembelajaran, mendorong peserta didik untuk percaya diri, berani mengajukan pendapat, dan kualitas pertanyaan/jawaban yang muncul juga semakin meningkat pada siklus kedua. Tampaklah bahwa pemanfaatan aplikasi iSpring Suite 8 telah meningkatkan kualitas pembelajaran.

Tabel 8. Kualitas Proses Pembelajaran Sebelum Tindakan

\begin{tabular}{|c|c|c|}
\hline No Aspek & Skor & Kualitas \\
\hline 1. Suasana Pembelajaran & 1,8 & Kurang \\
\hline 2. Fokus pada Pembelajaran & 2,0 & Cukup \\
\hline 3. Tanggung jawab & 1,6 & Kurang \\
\hline 4. Rasa Percaya Diri & 1,3 & Kurang \\
\hline $\begin{array}{l}\text { Rata-Rata Nilai Kualitas } \\
\text { Proses Pembelajaran }\end{array}$ & 1,68 & Kurang \\
\hline
\end{tabular}

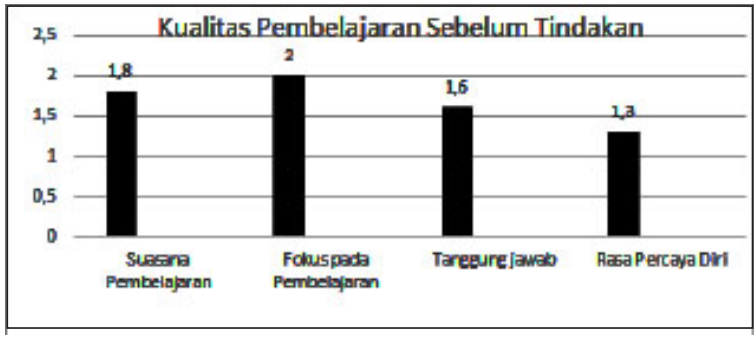

Gambar 8 Kualitas Pembelajaran Sebelum Tindakan

Rekapitulasi kualitas pembelajaran yang meliputi suasana pembelajaran yang menyenangkan, fokus pada pembelajaran, tanggung jawab, dan percaya diri sebelum tindakan memiliki, rata-rata skor 1,68 dengan kriteria kurang.

Tabel 9. Kualitas Proses Pembelajaran Siklus Pertama

\begin{tabular}{clll}
\hline No & Aspek & Skor & Kualitas \\
\hline 1. & Suasana Pembelajaran & 2,8 & Cukup \\
2. & Fokus pada Pembelajaran & 3,0 & Baik \\
3. & Tanggung jawab & 2,8 & Cukup \\
4. & Rasa Percaya Diri & 2,7 & Cukup \\
\hline & Rata-Rata Nilai Kualitas & $\mathbf{2 , 8 1}$ & Cukup \\
& Proses Pembelajaran & & \\
\hline
\end{tabular}

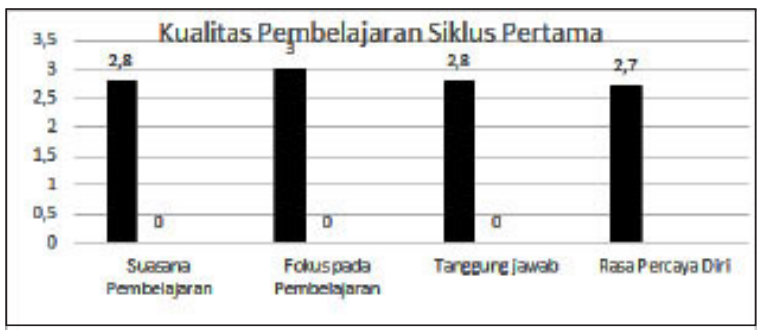

Gambar 9 Kualitas Pembelajaran Siklus Pertama 
Rekapitulasi kualitas pembelajaran yang meliputi suasana pembelajaran yang menyenangkan, fokus pada pembelajaran, tanggung jawab, dan percaya diri pada siklus pertama memiliki rata-rata skor 2,81 dengan kriteria cukup. Ini dikarenakan iSpring adalah alat yang memberikan beberapa fitur pada PowerPoint yang di dalamnya terdapat karakter simulasi dialog yang realistik dengan tambahan fitur evaluasi penilaian (Pritakinanthi, 2017: 61). Pengintegrasian iSpring dalam Ms. PowerPoint akan sangat bermanfaat bagi guru Matematika dalam membuat media pembelajaran yang akan digunakan dalam pengajarannya (Kartono, 2013: 430).

Tabel 10. Kualitas Proses

Pembelajaran Siklus Kedua

\begin{tabular}{|c|c|c|}
\hline NoAspek & Skor & Kualitas \\
\hline 1. Suasana Pembelajaran & 3,8 & Baik \\
\hline 2. Fokus pada Pembelajaran & 4,0 & Sangat Baik \\
\hline 3. Tanggung jawab & 3,8 & Baik \\
\hline 4. Rasa Percaya Diri & 3,7 & Baik \\
\hline $\begin{array}{l}\text { Rata-Rata Nilai } \\
\text { Kualitas Proses } \\
\text { Pembelajaran }\end{array}$ & 3,82 & Baik \\
\hline
\end{tabular}

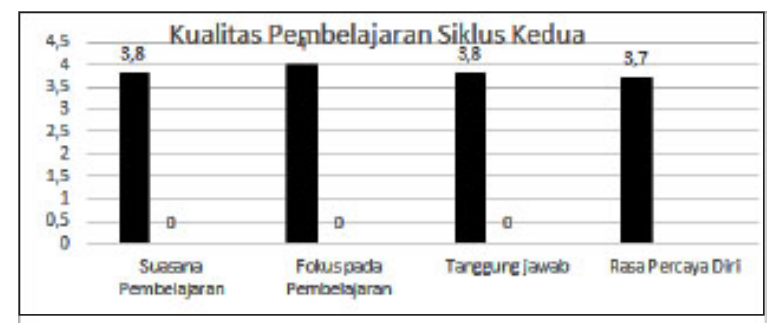

Gambar 10. Kualitas Pembelajaran Siklus Kedua

Rekapitulasi kualitas pembelajaran yang meliputi suasana pembelajaran yang menyenangkan, fokus pada pembelajaran, tanggung jawab, dan percaya diri pada siklus kedua, memiliki rata-rata skor 3,82 dengan kriteria baik. Hasil penelitian ini adalah bahwa pemanfaatan aplikasi iSpring Suite 8 dapat meningkatkan hasil belajar Matematika tentang materi himpunan kelas VII B SMP Muhammadiyah 1 tahun ajaran 2017/2018. Berdasarkan hasil tes, rata-rata hasil belajar peserta didik pada siklus pertama adalah 78,89 , yang tuntas sebanyak 27 siswa $(75,00 \%)$, dan yang tidak tuntas sebanyak 9 siswa $(25,00 \%)$.
Kemudian pada siklus kedua, berdasarkan hasil tes, rata-rata hasil belajar peserta didik adalah 86,39 dan ke-36 peserta didik (100\%) tuntas belajarnya. Siklus kedua lebih berhasil karena iSpring Suite 8 didesain dengan lebih menarik. Hasil penelitian ini relevan dengan hasil penelitian Wagino bahwa setelah memanfaatkan aplikasi iSpring, sebagian besar peserta didik sangat antusias mengikuti kegiatan ini karena materi yang diberikan sangat bermanfaat dan menarik. (Wagino, 2015: 22). Hasil penelitian ini relevan juga dengan penelitian Suprapti yang mengungkapkan bahwa penerapan aplikasi iSpring dapat meningkatkan kemampuan matematika pada anak (Suprapti, 2015:1). Dengan menggunakan aplikasi ispring, nantinya dapat di-convert menjadi video, flash, dII. Media dan aplikasi tersebut dapat dikatakan sebagai ICT (Afandi, 2017: 20). Media pembelajaran telah terbukti berperan aktif untuk meningkatkan motivasi dan intelektual siswa dalam proses pembelajaran (Firmadani, 2017: 171).

\section{SIMPULAN DAN SARAN}

Pemanfaatan aplikasi iSpring Suite 8 dalam pembelajaran Matematika untuk materi operasi pada himpunan di kelas VII B SMP Muhammadiyah 1 Surabaya dapat meningkatkan hasil belajar peserta didik. Hal ini terlihat dari adanya peningkatan ketuntasan belajar individual, peningkatan nilai rata-rata hasil belajar, dan peningkatan kualitas pembelajaran.

Pemanfaatan aplikasi iSpring Suite 8 dapat meningkatkan hasil belajar Matematika tentang materi himpunan untuk kelas VII B SMP Muhammadiyah 1 tahun ajaran 2017/ 2018. Kesimpulan ini didasarkan atas hasil tes. Pada pembelajaran siklus pertama didapatkan rata-rata hasil belajar siswa 78,89, di mana yang tuntas pada siklus pertama adalah 27 peserta didik (75,00\%) dan yang tidak tuntas ada 9 siswa (25,00\%). Berdasarkan hasil tes, rata-rata hasil belajar peserta didik dalam pembelajaran pada siklus kedua didapatkan 86,39 dengan 36 peserta didik (100\%) tuntas belajarnya. Pada siklus kedua ini, peserta didik lebih berhasil karena 
iSpring Suite 8 yang didesain lebih menarik minat belajar peserta didik.

Rekapitulasi kualitas pembelajaran yang meliputi suasana pembelajaran yang menyenangkan, fokus pada pembelajaran, tanggung jawab, dan percaya diri sebelum tindakan, memiliki rata-rata skor 1,68 dengan kriteria kurang. Pada siklus pertama, rata-rata skor 2,81 dengan kriteria cukup. Kemudian, pada siklus kedua, rata-rata skornya menjadi 3,82 dengan kriteria baik.

Berdasarkan simpulan tersebut di atas, penulis mengajukan saran agar guru Matematika: (1) lebih inovatif dalam tampilan

\section{PUSTAKA ACUAN}

\section{Buku}

Mulyasa. 2011. Menjadi Guru Profesional Menciptakan Pembelajaran Kreatif dan Menyenangkan. Bandung: Remaja Rosdakarya.

Roestiyah. 2012. Strategi Belajar Mengajar. Jakarta: Rineka Cipta.

Rohani, Ahmad. 2010. Pengelolaan Pengajaran. Jakarta: PT Rineka Cipta.

Suhardjono. 2011. Penelitian Tindakan Kelas Sebagai Kegiatan Pengembangan Profesi Guru. Jakarta: Bumi Aksara.

Tamimuddin, Muh. 2014. Membuat Konten Pembelajaran dengan PowerPoint dan iSpring Suite 8. Yogyakarta: PPPPTK Matematika.

\section{Jurnal/prosiding/disertasi/tesis/skripsi}

Afandi, Ahmad. 2017. Media ICT dalam Pembelajaran Matematika Menggunakan PowerPoint Interaktif dan iSpring Presenter. Jurnal Terapan Abdimas, Volume 2, Januari 2017.

Alhamuddin. 2012. Pemanfaatan ICT dalam Pembelajaran. jurnal.upi.edu/file/ $P E M A N F A T A N N_{-}$I C T DALAM_PEMBELAJARAN.pdf (diunduh tanggal 12 September 2014 jam 13.00). Bandung UPI

Ardiansyah. 2016. Pengaruh Metode Partisipatori terhadap hasil Belajar Matematika. Jurnal SAP presentasinya dengan memanfaatkan aplikasi iSpring Suite 8 yang mudah didapat dari internet untuk peningkatan kualitas pembelajaran, khususnya peningkatan ketuntasan belajar individual dan peningkatan nilai rata-rata hasil belajar; dan (2) mampu memanfaatkan aplikasi iSpring Suite 8 dengan berbagai penambahan dan variasi sehingga dapat menciptakan suasana pembelajaran yang lebih menyenangkan, membuat peserta didik lebih fokus pada pembelajaran, tanggung jawab peserta didik lebih meningkat, dan peserta didik menjadi lebih percaya diri mengikuti pembelajaran.

Vol. 1 No. 1 Agustus 2016 ISSN: 2527-967X 61 Program Studi Teknik Informatika, Universitas Indraprasta PGRI.

Firmadani, Fifit. 2017. Pelatihan Pembuatan Media pembelajaran Interaktif dengan iSpring Presenter bagi Guru MI AL Islam Balesari Kecamatan Windusari Kabupaten Magelang. Jurnal Conference on Language and Language Teaching.

Frengky. 2008. Model Pembelajaran Matematika Siswa Kelas Satu Sekolah Dasar. Jurnal Psikologi Fakultas Psikologi Universitas Gadjah Mada VOLUME 35, NO. 2, ISSN: 0215-8884. Yogyakarta, UGM.

Ibrahim, Nurdin, 2004. Studi Penyelenggaraan Jaringan Sekolah. Jakarta: Jurnal Teknodik No 14/VIII/TEKNODIK/JUNI/2004. Ciputat, Pustekkom Kemdikbud.

Kartono. 2013. Pemanfaatan MS PowerPoint dan Ispring dalam Pembelajaran Matematika Berbasis Technological Pedagogigal Content Knowledge (TPACK) sebagai Upaya Optimalisasi Implementasi Kurikulum 2013. Prosiding yang disajikan dalam Temu Ilmiah Nasional Guru (TING) VI di Universitas Terbuka. Tangerang Selatan, Universitas Terbuka.

Martiningsih. 2007. Prestasi Belajar Matematika Siswa Kelas IX SMP AI Muslim Sidoarjo Sebelum dan Sesudah Pembelajaran dengan 
TVE. Jurnal Teknodik No 21/XI/TEKNODIK/ Agustus/2007. Ciputat, Pustekkom Kemendikbud.

Pritakinanthi, Arlitya Stri. 2017. Pengembangan Media Pembelajaran Menggunakan iSpring untuk Meningkatkan Hasil Belajar Mata Pelajaran Bahasa Inggris Kelas VIII SMP Negeri 37 Semarang. Skripsi. Semarang: Universitas Negeri Semarang Fakultas IImu Pendidikan.

Rahmah, Devi Yulia. 2017. Pengembangan Media Interaktif Berbasis I-Spring untuk Peningkatan Hasil Belajar Siswa Kelas V di Madrasah Ibtidaiyah Negeri Loloan Timur Jembrana Bali. Malang: Universitas Islam Negeri Maulana Malik Ibrahim.

Suprapti, Endang. 2015. Peningkatan Pembelajaran Matematika Anak Usia Dini dengan Microsoft PowerPoint Ispring pada Materi Pengenalan Konsep Bilangan. Jurnal Pedagogi, Volume 2 Nomor 2, Februari-2015.
Sunaengsih, Cucun. 2016. Pengaruh Media Pembelajaran terhadap Mutu Pembelajaran pada Sekolah Dasar Terakreditasi A. Jurnal Mimbar Sekolah Dasar, Vol 3(2) 2016, 183190 DOI: 10.17509/mimbar-sd.v3i2.4259.

Wagino, et. al. 2015. Pembuatan Media Pembelajaran Interaktif dengan Perangkat Lunak Ispring Presenter di SMAN 4 Banjarmasin. Jurnal Al-Ikhlas ISSN 2461-0992 Volume 1 Nomor 1, Oktober 2015.

Ubaidah, Nila. 2016. Pemanfaatan CD Pembelajaran untuk Meningkatkan Kemampuan Komunikasi Matematis Siswa melalui Pembelajaran Make a Match. Jurnal Pendidikan Matematika FKIP Unissula Volume 4 (1) 2016 ISSN: 2338-5988.

Wahyudi, Nanang Gesang. 2016. Pengembangan Multimedia Pembelajaran Berbasis Adobe Flash pada Mata Pelajaran PAI Kelas $\mathrm{V}$ di SDIT AI-Hasna Klaten. Jurnal Penelitian Teknologi Pendidikan Volume 14 No. 01 Maret 2016. 